\title{
A METHOD FOR QUANTIFYING DEEP-SEA CARBONATE DISSOLUTION USING
${ }^{14}$ C DATING
}

\author{
S. A. VAN KREVELD, ${ }^{1}$ G. M. GANSSEN, ${ }^{1}$ J. E. VAN HINTE, ${ }^{1}$ M. M. MELKERT, ${ }^{1}$ \\ S. R. TROELSTRA, ${ }^{1} \mathrm{~K}$. VAN DER BORG ${ }^{2}$ and A. DE JONG ${ }^{2}$
}

\begin{abstract}
We quantified the rate of carbonate dissolution with increasing water depth by taking the difference in the carbonate mass accumulation rate of deep (3393-4375 m) core top sediments from the shallowest one $(3208 \mathrm{~m})$, which we assumed was unaffected by dissolution. This method depends on high quality ${ }^{14} \mathrm{C}$ dates that we calibrated to calendar years $1.7 \mathrm{~g} \mathrm{~cm}^{-2} \mathrm{ka}^{-1}$ ) carbonate dissolution rates, show low (ranging from 0 to $0.3 \mathrm{~g} \mathrm{~cm}^{-2} \mathrm{ka}^{-1}$ ) and high (ranging from 1.5 to in increase in the carbonate dissolution rate at $4000-\mathrm{m}$ water depth to mark the lysocline.
\end{abstract}

\section{INTRODUCTION}

Calcium carbonate deposition in the world's oceans is an important component of the global carbon cycle. Because changes in the rate of carbonate dissolution affect carbonate accumulation, they must be quantified. Previous attempts to estimate carbonate dissolution by means of percent carbonate (Balsam 1983; Farrell and Prell 1989), selective dissolution of foraminiferal (Berger 1970; Parker and Berger 1971: Berger and von Rad 1972; Berger 1976), and coccolith assemblages (McIntyre and McIntyre 1971; Berger 1973a; Roth and Berger 1975; Schneidermann 1977), benthic to planktonic foraminifera ratios, percent fragments or a combination of these methods (Arrhenius 1952; Thunell 1976; Malmgren 1983) were qualitative. Francois, Bacon and Suman (1990) quantified carbonate dissolution using ${ }^{230} \mathrm{Th}$; de Vernal et al. (1992) used the relative abundance of $\mathrm{CaCO}_{3}$ shells and organic linings of benthic foraminifera. We present here a simple method for quantifying carbonate dissolution using the decrease in the carbonate mass accumulation rate with increasing water depth. Note that our carbonate dissolution rate estimates reflect only the amount of calcite dissolved and not aragonite. A slight change in sedimentation rate affects the carbonate mass accumulation rate and eventually the carbonate dissolution rate estimate. Thus, it is essential to have high-quality
${ }^{14} \mathrm{C}$ dates.

\section{METHODS}

We used six box-core sediment tops recovered in the Northeast Atlantic between $44^{\circ}-47^{\circ} \mathrm{N}$ and $20^{\circ}-24^{\circ} \mathrm{W}$ from $3208-4375 \mathrm{~m}$ water depths (Fig. 1, Table 1 ). These cores were collected during JGOFS, Leg 4 cruise aboard R/V Tyro in June 1990. Carbonate dissolution quantification involves ${ }^{14} \mathrm{C}$ dating of two sediment samples taken from the top and from a deeper level in each box core, respectively (Fig. 2, Table 2). These ages were calibrated to calendar dates using the marine bidecadal data set (Stuiver and Braziunas 1993) of CALIB 3.0 (Stuiver and Reimer 1993), which already includes a modeled, time-dependent reservoir correction of $c a .402 \mathrm{yr}$ for the global ocean (Stuiver and Braziunas 1993). We assume that our Northeast Atlantic planktonic foraminifera samples come from an environment similar to the model world ocean, thus the regional reservoir age correction $(\Delta R)=0$ (Stuiver and Braziunas 1993).

\footnotetext{
${ }^{1}$ Center for Marine Earth Sciences, Free University, De Boelelaan 1085, NL-1081 HV Amsterdam, The Netherlands

${ }^{2}$ Robert J. van de Graaff Laboratorium, State University Utrecht, Box 80.000, NL-3508 TA Utrecht, The Netherlands
} 


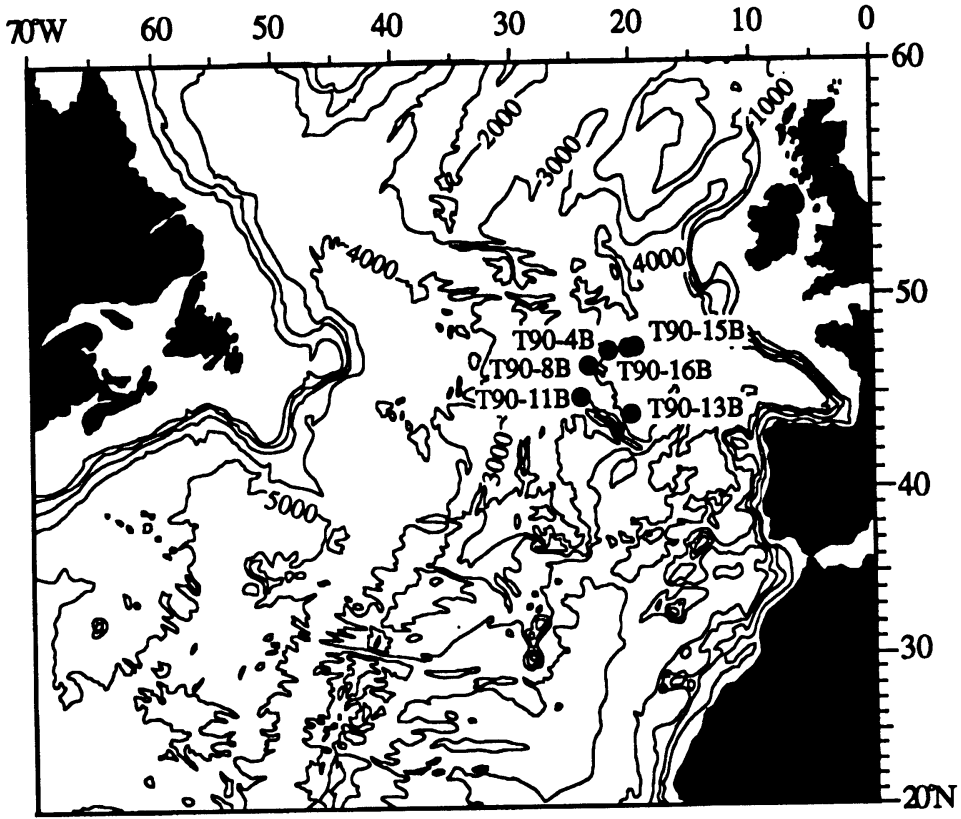

Fig. 1. Physiographic map of the Northeast Atlantic Ocean showing the position of the box cores between $44-47^{\circ} \mathrm{N}$ and $20-24^{\circ} \mathrm{W}$. These cores were recovered from 3208-4375-m water depths. Depth contours are given in meters.

TABLE 1. Location, Water Depth and Length of the Recovered Box Cores

\begin{tabular}{lcccc}
\hline Box core & Latitude & Longitude & $\begin{array}{c}\text { Water } \\
\text { depth }(\mathrm{m})\end{array}$ & $\begin{array}{c}\text { Core length } \\
(\mathrm{cm})\end{array}$ \\
\hline T90-11B & $44^{\circ} 59.8^{\prime} \mathrm{N}$ & $24^{\circ} 39.6^{\prime} \mathrm{W}$ & 3208 & 23 \\
T90-8B & $46^{\circ} 12.8^{\prime} \mathrm{N}$ & $23^{\circ} 42.9^{\prime} \mathrm{W}$ & 3393 & 30 \\
T90-4B & $47^{\circ} 10.3^{\prime} \mathrm{N}$ & $21^{\circ} 42.9^{\prime} \mathrm{W}$ & 3945 & 34 \\
T90-13B & $43^{\circ} 59.9^{\prime} \mathrm{N}$ & $20^{\circ} 01.0^{\prime} \mathrm{W}$ & 4016 & 31 \\
T90-15B & $47^{\circ} 37.2^{\prime} \mathrm{N}$ & $20^{\circ} 55.3^{\prime} \mathrm{W}$ & 4177 & 43 \\
T90-16B & $47^{\circ} 39.5^{\prime} \mathrm{N}$ & $20^{\circ} 55.8^{\prime} \mathrm{W}$ & 4375 & 45 \\
\hline
\end{tabular}

We calculated sedimentation rate by dividing the sediment thickness by the difference in the calendar calibrated ${ }^{14} \mathrm{C}$ ages for each box core, therefore assuming a constant sedimentation rate between these age-control points. Carbonate mass accumulation rate was calculated using

$$
\mathrm{cMAR}=\mathrm{SR} \times \mathrm{DBD} \times \% \mathrm{CaCO}_{3} \times 0.01
$$

where $\quad \mathrm{MAR}=$ carbonate mass accumulation rate $\left(\mathrm{g} \mathrm{cm}^{-2} \mathrm{ka}^{-1}\right)$

$\mathrm{SR}=$ sedimentation rate $\left(\mathrm{cm} \mathrm{ka}^{-1}\right)$

$\mathrm{DBD}=$ dry bulk density $\left(\mathrm{g} \mathrm{cm}^{-3}\right)$.

Assuming that the initial carbonate deposition rate preserved in the shallowest core is the same for all cores, the difference in the carbonate accumulation rate with the deeper cores will give the rate of carbonate dissolution as a function of depth expressed as

$$
\mathrm{cDR}=\mathrm{cMAR}(\text { shallowest core })-\operatorname{cMAR}(\text { deeper core)} \text {. }
$$


These assumptions are viable because the cores were recovered from a small geographic area govpods and juvenile foraminifes and ecological regimes. Also, the shallowest core contains pteropods and juvenile foraminifera, indicating that it lies above the aragonite compensation depth and tion rate can be taken as the originate dissolution. Therefore, its carbonate (calcite) mass accumulanegligible in our shallowest core because we founde) deposition rate. We considered aragonite as the carbonate consists of calcite. Our carbonate dissolution few pteropod fragments and the bulk of dissolved.

We determined dry bulk density by weighing $12 \mathrm{~cm}^{3}$ of wet sediment after drying at $50^{\circ} \mathrm{C}$. This sediment was then wet-sieved through $32 \mu \mathrm{m}$ mesh screen and both the fine $(<32 \mu \mathrm{m})$ and the coarse $(>32 \mu \mathrm{m})$ fractions were collected and weighed.

The percent carbonate by weight of the bulk sample and the fine fraction was determined by a surements and the weights of the different fractions, with a precision of $\pm 2 \%$. Based on these meacalculated. Using accelerator mass spectrometry (AMS) ${ }^{14} \mathrm{C}$ measurements, we coarse fraction was samples consisting of handpicked, excellently pre ${ }^{14} \mathrm{C}$ measurements, we dated $12>250-\mu \mathrm{m}$

TABLE 2. ${ }^{14} \mathrm{C}$ Dates of $12>250 \mu \mathrm{m}$ Samples of Mixed Planktonic Foraminifera

\begin{tabular}{|c|c|c|c|c|c|c|}
\hline Box core & $\begin{array}{c}\text { Depth in core } \\
(\mathrm{cm})\end{array}$ & $\begin{array}{l}\text { Lab no. } \\
\text { (UtC) }\end{array}$ & $\begin{array}{c}\delta^{13} \mathrm{C} \\
(\% \circ \mathrm{PDB})^{*}\end{array}$ & ${ }^{14} \mathrm{C}(\mathrm{BP}) \dagger$ & $\begin{array}{c}\text { Calendar } \\
\text { age BP } \ddagger\end{array}$ & $1 \sigma \mathrm{cal} \mathrm{BP}$ \\
\hline T90-11B & $0-2$ & 2948 & 0.11 & $2430 \pm 50$ & 2050 & $2116-1983$ \\
\hline T90-11B & $8-10$ & 2949 & 0.97 & $3640 \pm 100$ & 3530 & $3460-3403$ \\
\hline Т90-8B & $0-2$ & 2918 & 0.64 & $2890 \pm 50$ & 2696 & $2723-2645$ \\
\hline T90-8B & $10-12$ & 2919 & 0.56 & $4230 \pm 50$ & 4235 & $4393-4241$ \\
\hline T90-4B & $0-2$ & 2912 & 0.55 & $3640 \pm 140$ & 3530 & $3690-3363$ \\
\hline Т90-4B & $16-18$ & 2913 & 0.50 & $5670 \pm 50$ & 6065 & $6153-5987$ \\
\hline Т90-13B & $0-2$ & 2953 & 0.82 & $2450 \pm 50$ & 2079 & $2133-2003$ \\
\hline Т90-13B & $16-18$ & 2954 & 0.96 & $6240 \pm 70$ & 6695 & $6753-6615$ \\
\hline T90-15B & $0-2$ & 2955 & 0.85 & $2980 \pm 110$ & 2741 & $2843-2683$ \\
\hline T90-15B & $18-20$ & 2956 & 0.73 & $6640 \pm 70$ & 7150 & $7196-7044$ \\
\hline T90-16B & $0-2$ & 2957 & 0.52 & $3070 \pm 70$ & 2815 & $2896-2751$ \\
\hline Т90-16B & $18-20$ & 2958 & 0.86 & $7150 \pm 60$ & 7559 & $7619-7523$ \\
\hline
\end{tabular}

\section{RESUlts AND DISCUSSION}

The sediments are calcareous oozes and marls, with the three deepest cores containing some volcanic rock fragments reaching a maximum diameter of $4 \mathrm{~mm}$ (Fig. 2). The surface sediments are carbonate oozes with a coarse carbonate fraction of planktonic foraminifera and pteropods with minor amounts of benthic foraminifera and ostracods, and a fine carbonate fraction of coccoliths and foraminiferal fragments. Only the shallowest surface sample collected at 3208-m water depth contained fragments of pteropods. The bulk carbonate content of the box core top samples varies from by weight of bulk carbongt, with a higher fine than coarse carbonate content (Fig. 3). The percent is no distinct trend for the individual fecreases gradually with increasing water depth, though there 


\section{LTTHOLOGIC AND WEIGHT PERCENT CARBONATE PROFILES}

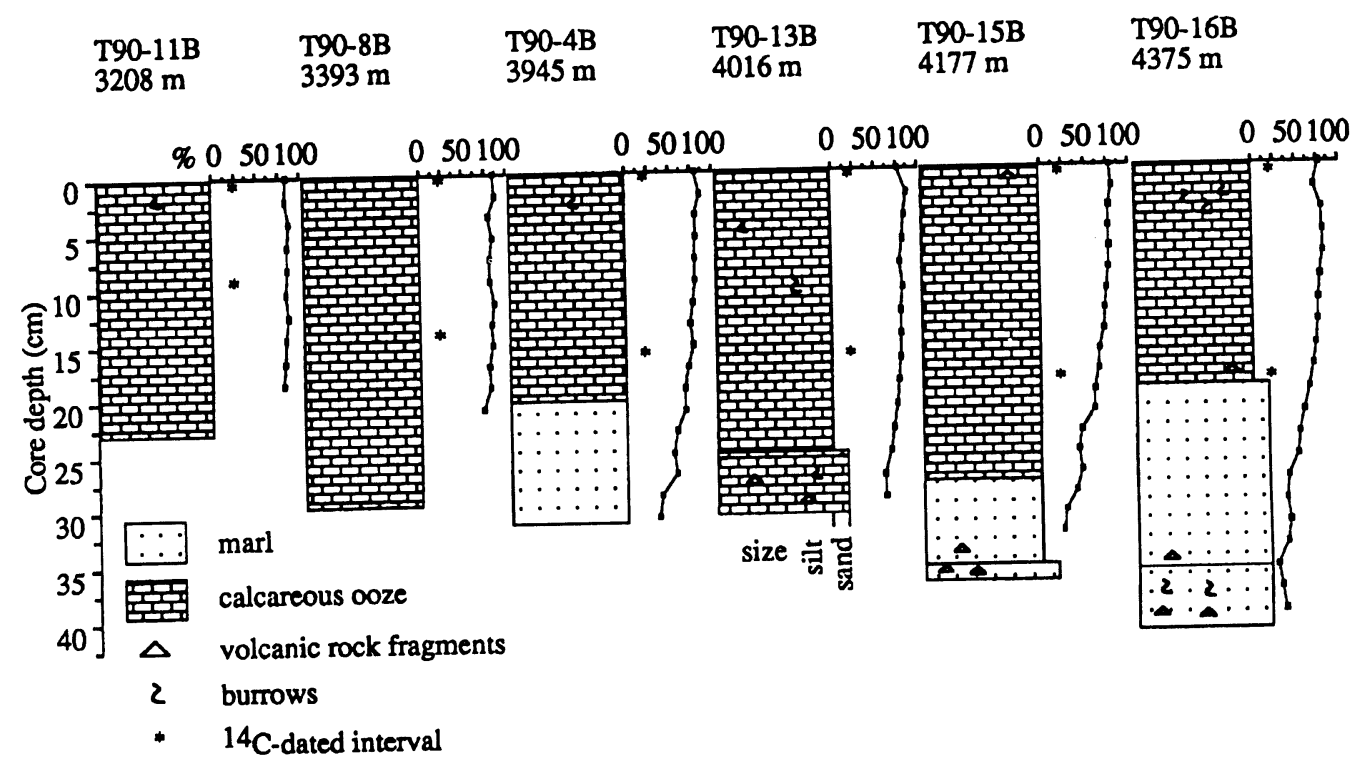

Fig. 2. Lithologic and percent carbonate by weight profiles of the box cores

Carbonate mass accumulation rate decreases with increasing water depth (Fig. 4), with a distinct drop at $4000 \mathrm{~m}$. Here, the drop in the coarse carbonate accumulation rate is about twice that of the fine carbonate, implying that dissolution affects the former more than the latter. However, we cannot say this for certain because we find fragments of planktonic foraminifera incorporated in the fine fraction.

Carbonate dissolution rate increases with increasing water depth (Fig. 5). These rates are very low, ranging from 0 to $0.3 \mathrm{~g} \mathrm{~cm}^{-2} \mathrm{ka}$ between 3208 and $3945 \mathrm{~m}$ and suddenly increasing to $1.5 \mathrm{~g} \mathrm{~cm}^{-2} \mathrm{ka}$ at $4016 \mathrm{~m}$, reaching a maximum of $1.7 \mathrm{~g} \mathrm{~cm}^{-2} \mathrm{ka}$ in the deepest sample $(4375 \mathrm{~m})$ when calculated using sedimentation rates based on calendar ages. In relative percentages, the carbonate loss increases from $0-7 \%$ to $42-48 \%$. The carbonate dissolution rate shows a remarkable increase at 4000-m water depth, which we interpret to mark the lysocline. This is in contrast to previous studies based on percent carbonate by weight, which show the lysocline to be several hundred meters deeper.

Previous studies (e.g., Heath, Moore and Dauphin 1976; Pisias 1976; Thiede, Suess and Müller 1982; Kuehl, Fuglseth and Thunell 1993) calculated sedimentation rates without converting the ${ }^{14} \mathrm{C}$ dates to calendar years. Our data show that these sedimentation rates can be about 14-20\% higher. These differences are reflected in the carbonate mass accumulation rate and eventually in the dissolution rate estimates.

The carbonate dissolution rate shows a remarkable increase at about 4000-m depth, which we interpret to mark the lysocline. This depth coincides with Berger's (1977) lysocline position for this area. However, other studies based on percent carbonate by weight (Biscaye, Kolla and Turekian 1976) and degree of planktonic foraminifera fragmentation, absence of fragile forms, pitted tests, and eroded apertures or internal walls, and large numbers of benthic foraminifera (Kipp 1976; see also Broecker and Takahashi 1978) show the lysocline at $4900 \mathrm{~m}$. Crowley (1983) estimated the lyso- 

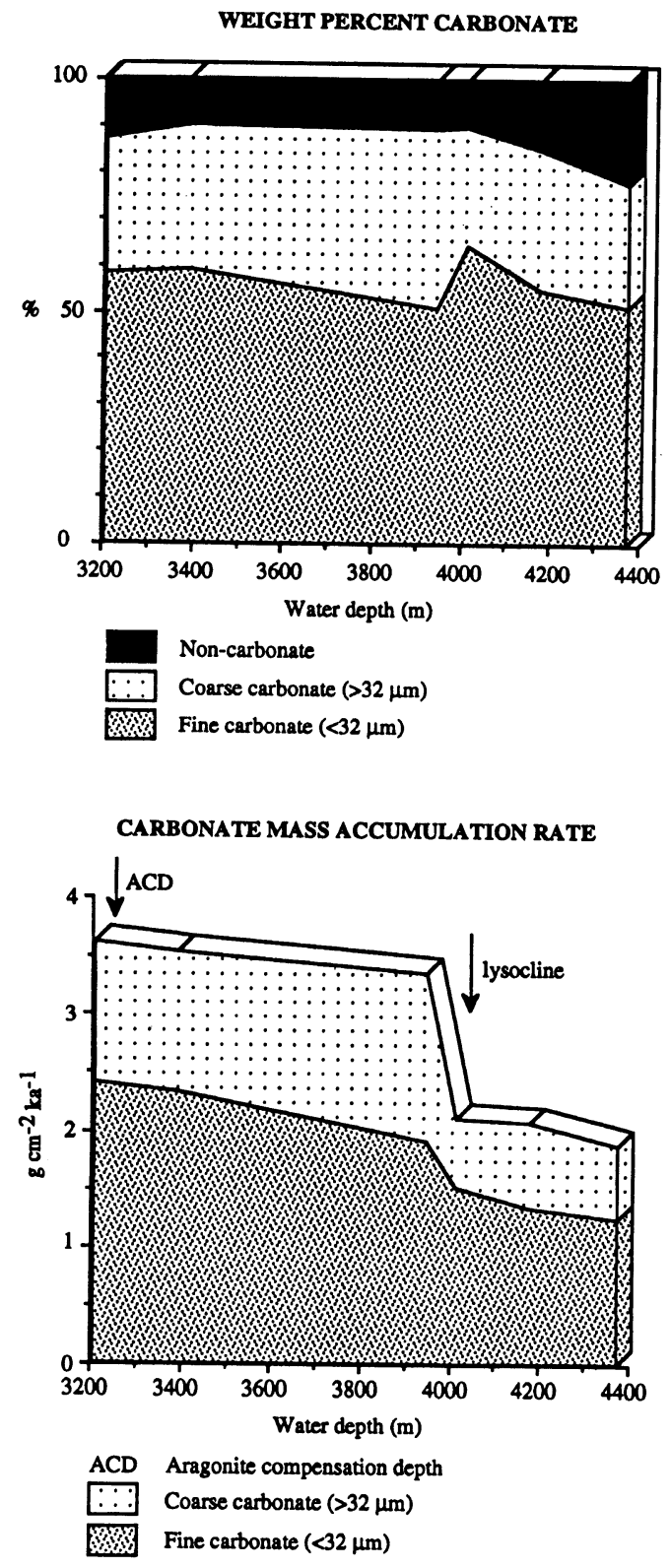

Fig. 3. The sediment core tops are composed of calcareous oozes with carbonate content varying from $90 \%$ down to $77 \%$ by weight
Fig. 4. Coarse $(>32 \mu \mathrm{m})$ and fine $(<32 \mu \mathrm{m})$ mass accumulation rate given in $\mathrm{g} \mathrm{cm}^{2} \mathrm{ka}^{-1}$ plotted against water depth

cline depth at $4500 \mathrm{~m}$ in the Canary Basin, based on the planktonic foraminifera fragmentation and percentage of benthic foraminifera.

The different methods used to estimate carbonate dissolution give various lysocline depths. The one based only on percent carbonate by weight underestimates the amount of carbonate dissolved because for sediments with high initial carbonate content, little change in the percent carbonate by weight occurs until about 50\% of the carbonate has dissolved (Morse 1973; Morse and Mackenzie 1990). From our data, we observe only a $13 \%$ decrease in percent carbonate by weight when $48 \%$ 


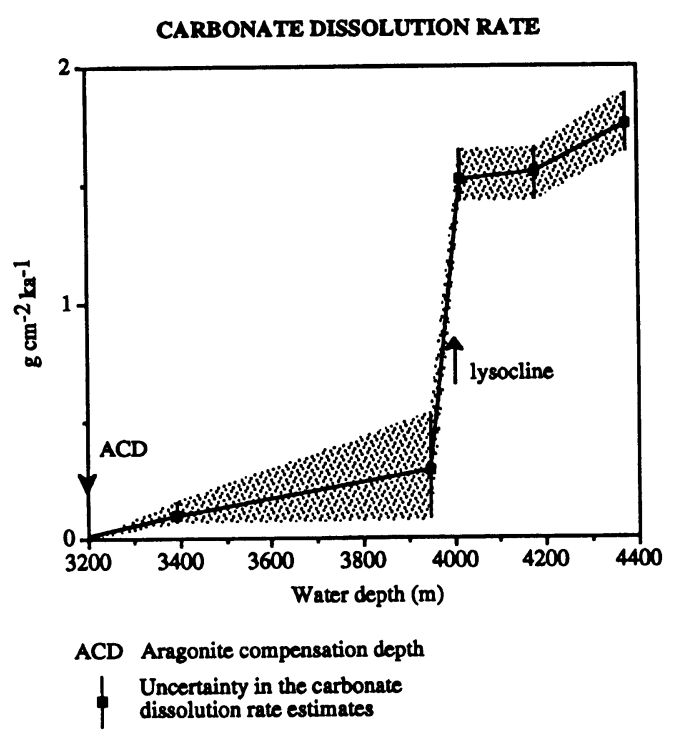

Fig. 5. Carbonate dissolution rate shows a remarkable increase at $4000-\mathrm{m}$ water depth, which we interpret to mark the lysocline. The uncertainty in the carbonate dissolution rate estimate is calculated using the $1 \sigma$ range of the calendar-calibrated age (Table 2) to calculate sedimentation rates and errors in the percent carbonate by weight and dry bulk density measurements.

of the carbonate has been dissolved (compare Figs. 3 and 5), consistent with Morse's (1973) estimates.

Likewise, the benthic to planktonic foraminifera ratio may underestimate carbonate dissolution. Benthic foraminifera are generally more resistant than planktonic foraminifera (Arrhenius 1952; Berger 1973b); therefore, an increase in the former may indicate enhanced dissolution. However, laboratory experiments show that some calcareous benthic foraminifera are less resistant than their most resistant planktonic counterparts (Adelseck 1978; Boltovskoy and Totah 1992). Additionally, Corliss and Honjo (1981) found varying dissolution susceptibilities among different benthic foraminiferal taxa by suspending specimens of various species in a deep-sea mooring. The use of the benthic to planktonic foraminifera ratio as a dissolution index probably accounts, in part, for the difference in our lysocline depth with those of Crowley (1983) and Kipp (1976).

Past carbonate dissolution estimates using percent carbonate, solution susceptibility of planktonic foraminifera and coccoliths, benthic-to-planktonic foraminifera ratios, and degree of fragmentation were qualitative (Ruddiman and Heezen 1967; McIntyre and McIntyre 1971; Berger 1976; Tappa and Thunell 1984; Peterson and Prell 1985; Naidu, Malmgren and Bornmalm 1993). We expect our results to allow for the calibration of these qualitative estimates in the study area. This calibration has to be repeated for each ecological province because carbonate dissolution is species-dependent and each zone has a distinct faunal/floral composition.

\section{CONCLUSION}

Deep-sea carbonate dissolution quantification is possible using the methodology presented here provided the cores are recovered from a small geographic area, so that the initial carbonate deposition rate can be assumed the same for all cores. It is also essential to have sufficient ${ }^{14} \mathrm{C}$ dates for calculating sedimentation rates. Our carbonate dissolution rate estimates show a remarkable increase at the 4000-m water depth, which we interpret to be the lysocline. 


\section{ACKNOWLEDGMENTS}

This manuscript benefitted from the critical review of G. S. Burr. We thank R. van Elsas, M. Konert and P. H. Willekes for measuring the carbonate content of the samples. The Leg 4 Joint Global Ocean Flux Study (JGOFS) expedition was sponsored by the Dutch Council of Sea Research (SOZ). This is publication 950505 of the Netherlands Research School of Sedimentary Geology, Center for Marine Earth Sciences, Free University, Amsterdam.

\section{REFERENCES}

Adelseck, C. G., Jr. 1978 Dissolution of deep-sea carbonate: Preliminary calibration of preservational and morphologic aspects. Deep-Sea Research 25: 1167-1185.

Arrhenius, G. 1952 Sediment cores from the East Pacific. Reports of the Swedish Deep-Sea Expedition, 19471948: 1-227.

Balsam, W. L. 1983 Carbonate dissolution on the Muir Seamount (Western North Atlantic): Interglacial/glacial changes. Journal of Sedimentary Petrolology 53 (3): 719-731.

Berger, W. H. 1970 Planktonic foraminifera: Selective solution and the lysocline. Marine Geology 8: 111138.

1973a Deep-sea carbonates: Evidence for a coccolith lysocline. Deep-Sea Research 20: 917-921. 1973b Deep-sea carbonates: Pleistocene dissolution cycles. Journal of Foraminiferal Research 3(4): 187195.

1976 Biogenous deep-sea sediments: Production and preservation. In Riley, J. P. and Chester, R., eds., Chemical Oceanography. London, Academic Press: 429-455.

1977 Carbon dioxide excursions and the deep-sea record: Aspects of the problem. In Andersen, N. R. and Malahoff, A., eds., The Fate of Fossil Fuel $\mathrm{CO}_{2}$ in the Oceans. New York, Plenum Press: 505-542.

Berger, W. H. and von Rad, U. 1972 Cretaceous and Cenozoic sediments from the Atlantic Ocean. Deep-Sea Drilling Project Initial Reports 14: 787-954.

Biscaye, P. E., Kolla, V. and Turekian, K. K. 1976 Distribution of calcium carbonate in surface sediments of the Atlantic Ocean. Journal of Geophysical Research 81: 2595-2603.

Boltovskoy, E. and Totah V. I. 1992 Preservation index and preservation potential of some foraminiferal species. Journal of Foraminiferal Research 22(3): 267273.

Broecker, W. S. and Takahashi, T. 1978 The relationship between lysocline depth and in situ carbonate ion concentration. Deep-Sea Research 25: 65-95.

Bruin, P. 1937 Enige ervaringen bij de bepaling van het gehalte van grond aan koolzure kalk volgens de methode Scheibler. Chemisch Weekblad 34: 755-759.

Corliss, B. H. and Honjo, S. 1981 Dissolution of deep-sea benthonic foraminifera. Micropaleontology 27: 356378.

Crowley, T. J. 1983 Calcium-carbonate preservation pat- terns in the central North Atlantic during the last 150,000 years. Marine Geology 51: 1-14.

de Vernal, A., Bilodeau, G., Hillaire-Marcel, C. and Kassou, N. 1992 Quantitative assessment of carbonate dissolution in marine sediments from foraminifer linings vs. shell ratios: Davis Strait, northwest North Atlantic. Geology 20: 527-530.

Farrell, J. W. and Prell, W. L. 1989 Climatic change and $\mathrm{CaCO}_{3}$ preservation: $\mathrm{An} 800,000$ year bathymetric reconstruction from the central equatorial Pacific ocean. Paleoceanography 4(4): 447-466.

Francois, R., Bacon, M. P. and Suman, D. O. 1990 Thorium 230 profiling in deep-sea sediments: High resolution records of flux and dissolution of carbonate in the equatorial Atlantic during the last 24,000 years. Paleoceanography 5(5): 761-787.

Heath, G. R., Moore, T. C., Jr. and Dauphin, J. P. 1976 Late Quaternary accumulation rates of opal, quartz, organic carbon, and calcium carbonate in the Cascadia Basin area, Northeast Pacific. In Cline, R. and Hays, J., eds., Investigation of Late Quaternary Paleoceanography and Paleoclimatology. Geological Society of America Memoir 145: 393-409.

Kipp, N. G. 1976 New transfer-function for estimating past sea-surface conditions from sea-bed distributions of planktonic foraminiferal assemblages in the North Atlantic. In Cline, R. and Hays, J., eds., Investigation of Late Quaternary Paleoceanography and Paleoclimatology. Geological Society of America Memoir 145: 3-41.

Kuehl, S. A., Fuglseth, T. J. and Thunell, R. C. 1993 Sediment mixing and accumulation rates in the Sulu and South China Seas: Implications for organic carbon preservation in deep-sea environments. Marine Geology 11: 15-35.

Malmgren, B. 1983 Ranking of dissolution susceptibility of planktonic foraminifera at high latitudes of the South Atlantic Ocean. Marine Micropaleontology 8: 183-191.

McIntyre, A. and McIntyre, R. 1971 Coccolith concentrations and differential solution in oceanic sediments. In Funnel, B. M. and Riedel, W. R., eds., The Micropaleontology of the Oceans. London, Cambridge University Press: 253-261.

Morse, J. W. (ms.) 1973 The dissolution kinetics of calcite: A kinetic origin for the lysocline. Ph.D. dissertation, Yale University. 
Morse, J. W. and Mackenzie, F. T. 1990 Geochemistry of sedimentary carbonates. Amsterdam, Elsevier: 707 p.

Naidu, P. D., Malmgren, B. A. and Bornmalm, L. 1993 Quaternary history of calcium carbonate fluctuations in the western equatorial Indian Ocean (Somali Basin). Palaeogeography, Palaeoclimatology, Palaeoecology 103: 21-30.

Parker, W. K. and Berger, W. H. 1971 Faunal and solution patterns of planktonic foraminifera in surface sediments of the South Pacific. Deep-Sea Research 18: 73-107.

Peterson, L. C. and Prell, W. L. 1985 Carbonate dissolution in Recent sediments of the Eastern Equatorial Indian Ocean: Preservation patterns and carbonate loss above the lysocline. Marine Geology 64: 259-290.

Pisias, N. G. 1976 Late Quaternary sediment of the Panama Basin: sedimentation rates, periodicities, and controls of carbonate and opal accumulation. In Cline, R. and Hays, J., eds., Investigation of Late Quaternary paleoceanography and paleoclimatology. Geological Society of America Memoir 145: 375-391.

Roth, P. H. and Berger, W. H. 1975 Distribution and dissolution of coccoliths in the south and central Pacific. In Sliter, W. V., Bé, A. W. H. and Berger, W. H., eds., Dissolution of Deep-Sea Carbonates. Cushman Foundation for Foraminiferal Research Special Publication 13: 87-113.
Ruddiman, W. F. and Heezen, B. C. 1967 Differential solution of planktic foraminifera. Deep-Sea Research 14: 801-808.

Schneidermann, N. 1977 Selective dissolution of Recent coccoliths in the Atlantic Ocean. In Ramsay, A. T. S., ed., Oceanic Micropaleontology. New York, Academic Press: 1009-1053.

Stuiver, M. and Braziunas, T. 1993 Modeling atmospheric ${ }^{14} \mathrm{C}$ influences and ${ }^{14} \mathrm{C}$ ages of marine samples to 10,000 BC. In Stuiver, M., Long, A. and Kra, R. S., eds., Calibration 1993. Radiocarbon 35(1): 137-189.

Stuiver, M. and Reimer, P. 1993 Extended ${ }^{14} \mathrm{C}$ data base and revised CALIB $3.0{ }^{14} \mathrm{C}$ age calibration program. In Stuiver, M., Long, A. and Kra, R. S., eds., Calibration 1993. Radiocarbon 35(1): 215-230.

Tappa, E. and Thunell, R. 1984 Late Pleistocene glacial/ interglacial changes in planktonic foraminiferal biofacies and carbonate dissolution patterns in the Vema Channel. Marine Geology 58: 101-122.

Thiede, J., Suess, E. and Müller, P. 1982 Late Quaternary fluxes of major sediment components to the sea floor at the Northwest African continental slope. In von Rad, U. et al, eds., Geology of the Northwest African Continental Margin. Berlin, Springer-Verlag: 605-631.

Thunell, R. C. 1976 Optimum indices of calcium carbonate dissolution in deep-sea sediments. Geology 4: 525-528. 